\title{
Nutrition Society Symposium on 'End points in clinical nutrition trials' Death, morbidity and economics are the only end points for trials
}

\author{
Ronald L. Koretz \\ Division of Gastroenterology, Olive View-UCLA Medical Center, 14445 Olive View Drive, Sylmar, \\ California 91342, USA and UCLA School of Medicine, Los Angeles, California, USA
}

\begin{abstract}
In order to determine whether surrogate markers predict clinical outcome, randomized controlled trials (RCT) of nutrition support $v$. no nutrition support that have reported at least one clinical outcome (mortality, infections, total complications, or duration of hospitalization) and at least one nutritional outcome (energy or protein intake, weight gain, $\mathrm{N}$ balance, albumin, prealbumin, transferrin, three anthropometric measures, skin testing, lymphocyte count) were assessed for concordance. If changes in nutritional markers predict clinical outcome, changes in both outcomes should go in the same direction. Concordance is defined as both outcomes changing in the same direction or both outcomes showing no difference. Discordance is defined as one outcome changing and the other not (partial) or both outcomes changing in opposite directions (complete). Ninety-nine RCT were identified, of which most were underpowered to see statistically significant changes, especially in clinical outcomes. Thus, the results were analysed only in relation to the direction of the respective changes in outcomes. Forty-eight comparisons $(4 \times 12)$ were made. The rates of concordance were $\leq 50 \%$ in forty-one of fortyeight comparisons; the rate was never $>75 \%$. A complete discordance rate of $\geq 25 \%$ was present in forty-three ( $\geq 50 \%$ in thirteen) of the forty-eight comparisons. The discordance was usually a result of the nutritional outcome being better than the clinical outcome. Changes in nutritional markers do not predict clinical outcomes. Before adopting any surrogate marker as an end point for a clinical trial, it has to be known that improving it will result in patient benefit.
\end{abstract}

Nutrition support: Outcomes: Surrogate outcomes: Intermediate outcomes: End points

'In order for a difference to be a difference, it must make a difference.'

Approximately 70 years ago Studley (1936) noted that patients who had lost $\geq 20 \%$ of their body weight before surgery for peptic ulcer disease had a higher mortality than patients with the same condition but more modest weight losses. Subsequent observational studies have confirmed this association between malnutrition and an adverse clinical outcome in patients with other diseases (Buzby et al. 1980; Reinhardt et al. 1980; Baker et al. 1982). It is also known that even if healthy individuals are deprived of adequate nutrients for a long enough period of time adverse clinical events resulting from starvation will develop (Keys, 1962). For both these reasons it has seemed reasonable to provide nutrition support to patients who are (or are at risk of becoming) malnourished.

The first form of such artificial nutrition support (parenteral) became available in the 1960s (Rhoads et al. 1981). These intravenous, and subsequent enteral, formulations were marketed as 'foods'; as such, 'efficacy' was established by showing that nutritional status was maintained (Dudrick et al. 1968). However, it must be appreciated that while such maintenance may be appropriate in healthy growing organisms with very limited nutritional reserves (e.g. otherwise healthy newborn animals or infants), the intent of nutrition support is to improve the clinical outcome of a wide variety of diseases

\footnotetext{
Abbreviations: RCT, randomized controlled trials.

Corresponding author: Professor Ronald L. Koretz, fax +1 818364 4573, email rkoretz@ladhs.org
} 
(Dudrick \& Ruberg, 1971). From this perspective, variables of nutritional maintenance (e.g. body weight or $\mathrm{N}$ balance) become intermediate or surrogate end points.

It is a well-established principle of evidence-based medicine that it cannot simply be assumed that improving intermediate end points translates into clinical improvement (reduction in mortality or morbidity). For example, patients with chronic rheumatoid arthritis frequently have anaemia; however, there is no reason to believe that simply increasing the $\mathrm{Hb}$ concentration will have any impact on the ravages of the joint disease. Before improvements in surrogate outcomes can be accepted as predictors of clinical benefits, it must at least be demonstrated (in randomized controlled trials (RCT) comparing intervention with no intervention) that altering those intermediate outcomes is associated with a similar alteration in the clinical outcomes.

Such supportive evidence does exist for some intermediate outcomes. For example, a mathematical analysis comparing surrogate and clinical outcomes in randomized treatment trials of patients with AIDS has demonstrated that, at least over the long-term, titres of human HIV RNA are a reliable surrogate marker for survival (HIV Surrogate Marker Collaborative Group, 2000). It is the intention of the present paper to compare the clinical and nutritional outcomes in RCT that have compared nutrition support with no nutrition support and have provided data that can be evaluated.

\section{Concordance and discordance}

As noted, a necessary condition for accepting the ability of a surrogate marker to predict a clinical outcome is the presence of a parallel or concordant effect. In other words, a study that shows an improvement or adverse effect in the surrogate marker also has to show the same effect in the clinical outcome, and a study that fails to show a difference in one outcome will also fail to show a difference in the other. 'Discordance' will be defined as a situation when the two outcomes do not agree. These concepts are illustrated in Table 1. If discordance exists, the ability of the nutritional outcome to predict the clinical outcome cannot be relied on.

A systematic review of the nutrition literature has been undertaken to identify RCT that have compared parenteral nutrition, intravenous protein-sparing therapy (the intravenous delivery of amino acids with relatively low amounts of non-nitrogenous energy) or enteral nutrition with no nutritional intervention (true control) and have reported at least one clinical and one nutritional outcome; the methodology of the literature search has been previously described (Koretz et al. 2001). The clinical outcomes of interest were mortality, infectious complications, total (including infectious and non-infectious) complications and duration of hospitalization. (Although cost issues would also be of interest, very little such information was available from the RCT.) The nutritional outcomes that were sought included intake of energy or protein, change in body weight, $\mathrm{N}$ balance, serum albumin, anthropometrics (triceps skinfold thickness, mid-arm circumference and mid-arm muscle circumference), other visceral proteins (transferrin, prealbumin), skin tests and total lymphocyte counts. A total of twenty-one RCT of enteral nutrition, fifty-nine RCT of parenteral nutrition and nineteen RCT of protein-sparing therapy were identified; they are listed in the Appendix.

All the RCT that have reported a particular clinical outcome and a particular nutritional outcome were entered in a table constructed like the example shown in Table 1. Since there were four clinical outcomes and twelve nutritional outcomes, forty-eight such tables were created. However, many of the individual trials contained relatively few subjects; when only statistically significant differences were considered, the RCT tended to cluster in the middle cell of Table 1 (concordance). For a few of the nutritional outcomes (e.g. body weight or $\mathrm{N}$ balance), significant differences were commonly found in all the trials, irrespective of size, so that the RCT tended to cluster in the upper middle cell of Table 1 (partial discordancenutritional outcome better than clinical outcome). The former situation created an appearance of concordance and the latter one of discordance when the real issue may have been the size of the study. Since statistically significant differences (particularly in underpowered trials) would be an unreasonable expectation, the primary analysis was performed considering only arithmetic differences. (In this way, when $\mathrm{N}$ balance was significantly improved, even an arithmetically-better clinical outcome would result in the RCT being judged as concordant.) The results of these primary analyses will be discussed.

It was decided a priori that when a trial included more than one treated group all the results would be pooled and compared with the control group (to avoid an overrepresentation of such studies in the analysis). The only exception to this rule was to be reports in which one group received enteral nutrition and another group received

Table 1. Nutritional $v$. clinical outcomes in randomized control trials

\begin{tabular}{lllcc}
\hline & \multicolumn{1}{c}{ Effect } & & Clinical outcome \\
\cline { 3 - 5 } & Better than control & $\begin{array}{c}\text { Better than } \\
\text { control }\end{array}$ & No different than control & Worse than control \\
\hline Nutritional outcome & $\mathrm{C}$ & PD-N better & CD-N better \\
& No different than control & PD-C better & C & PD-N better \\
& Worse than control & CD-C better & PD-C better & C \\
\hline
\end{tabular}

$\mathrm{C}$, concordance; PD, partial discordance; CD, complete discordance; $\mathrm{N}$ better, nutritional outcome better than clinical outcome; $\mathrm{C}$ better, clinical outcome better than nutritional outcome. 
parenteral nutrition; there was only one such report (Fletcher \& Little, 1986). Some papers failed to provide numerical data and only noted that there was "no difference' between the two groups; in such cases it was assumed that there were no arithmetic differences.

If reliance is going to be placed on these surrogate markers to predict the clinical outcome, the presence of very high concordances must be demanded (as this situation is analogous to the predictive value of a test). Simple mathematics indicates that if there is no relationship at all between clinical and nutritional outcomes 33\% of the RCT should appear to be concordant (since three of the nine cells are concordant).

\section{Are nutritional and clinical outcomes concordant?}

Not every RCT reported each of the four clinical and twelve nutritional outcomes. The number of trials that reported each one is listed in Table 2, along with the percentage that showed statistically significant or at least arithmetical differences favouring the treated group. As can be appreciated, the nutritional outcomes were improved (at least arithmetically) in $57-100 \%$ of the trials, whereas the clinical ones were improved in $32-55 \%$. This observation alone indicates that there will be some discordance.

The actual rates of concordance and discordance (partial and complete) are summarized in Table 3. The absence of a rate in a particular column indicates that none of the RCT provided data for such a combination. The rates of

Table 2. Impact of nutrition support on clinical and nutritional outcomes

\begin{tabular}{|c|c|c|c|c|c|}
\hline \multirow[b]{3}{*}{ Outcome } & \multirow{3}{*}{$\begin{array}{l}\text { No. of } \\
\text { studies }\end{array}$} & \multicolumn{4}{|c|}{ Improved by nutrition support } \\
\hline & & \multicolumn{2}{|c|}{$\begin{array}{l}\text { Statistically } \\
\text { significant }\end{array}$} & \multicolumn{2}{|c|}{$\begin{array}{c}\text { At least } \\
\text { arithmetic }\end{array}$} \\
\hline & & $n$ & $\%$ total & $n$ & $\%$ total \\
\hline \multicolumn{6}{|l|}{ Nutritional } \\
\hline Energy intake & 34 & 29 & 85 & 30 & 88 \\
\hline Protein intake & 19 & 17 & 89 & 18 & 95 \\
\hline Weight gain & 61 & 33 & 54 & 51 & 84 \\
\hline $\mathrm{N}$ balance & 43 & 39 & 91 & 43 & 100 \\
\hline Albumin & 62 & 7 & 11 & 35 & 57 \\
\hline TSF thickness & 32 & 8 & 25 & 20 & 63 \\
\hline MAC & 16 & 3 & 19 & 11 & 69 \\
\hline MAMC & 22 & 5 & 23 & 17 & 77 \\
\hline Transferrin & 28 & 11 & 39 & 21 & 75 \\
\hline Prealbumin & 23 & 8 & 35 & 21 & 91 \\
\hline Skin tests & 12 & 2 & 17 & 8 & 67 \\
\hline TLC & 9 & 0 & & 6 & 67 \\
\hline \multicolumn{6}{|l|}{ Clinical } \\
\hline Mortality & 87 & 1 & 1 & 36 & 41 \\
\hline Infections & 62 & 2 & 3 & 20 & 32 \\
\hline Total comp & 59 & 4 & 7 & 24 & 41 \\
\hline Dur'n hosp & 38 & 1 & 3 & 21 & 55 \\
\hline
\end{tabular}

TSF, triceps skinfold; MAC, mid-arm circumference; MAMC, mid-arm muscle circumference; TLC, total lymphocyte count; comp, complications; dur'n hosp, duration of hospitalization. concordance were rarely found to be $>50 \%$, and never $>75 \%$. (The two highest rates $(67 \%, 75 \%)$ were observed in situations in which only three and four RCT were available.) The rates of discordance were almost always a result of the nutritional outcome being better than the clinical outcome. It is perhaps even more disconcerting that the rates of complete discordance (the nutritional effect and the clinical effect going in opposite directions) were often almost as high (and occasionally higher) as the rates of concordance.

\section{Why is there so much discordance?}

Probably the major reason why surrogate outcomes are used is the belief that the outcome is pathophysiologically important in the disease. It is reasonable to view the titre of HIV RNA in this way; individuals with larger numbers of viral particles in the circulation will be more likely to have more lymphocytes subsequently infected. While it is known that malnourished patients have poorer outcomes than well-nourished patients with the same underlying disease, such an association does not establish causation. It may be that the malnutrition independently contributes morbidity; it may also be that the malnutrition is a reflection of worse disease. In the latter scenario malnutrition is simply a messenger telling the observer that a bad situation is present; shooting the messenger will not alter the content of the message. Given the discordance in the nutritional and clinical outcomes, it would seem more reasonable to believe this latter scenario, i.e. that the association is not causative.

This hypothesis has been tested in another arena. It is known that patients with hypoalbuminaemia have poorer clinical outcomes (Koretz, 1995). If albumin was itself responsible, improving the albumin level should result in better clinical outcomes. Curiously, the only debate in the literature is whether or not albumin infusions are harmful (Cochrane Injuries Group Albumin Reviewers, 1998; Wilkes \& Navickis, 2001).

\section{Conclusions}

Nutrition support may be useful in maintaining nutritional status. However, this action does not necessarily translate into meaningful clinical gain. Since this therapy is used as an adjunct for sick patients, it is the clinical gain that is the aim. In order to assess the ability of enteral or parenteral nutrition to alter the clinical course of any underlying disease process in a favourable way, it must be shown that its use will improve mortality or morbidity (and does so at a cost that is affordable in a resource-constrained environment).

There are hard data that demonstrate that such improvements cannot be assured simply because various surrogate nutritional outcomes are altered. Given this experience, it is necessary to be sceptical about the utility of other surrogate outcomes; before any surrogate marker is adopted as a desirable end point of a clinical trial, it must be known that changing it will provide a clinical benefit to the patient. 
Table 3. Rates of concordance and discordance between various clinical and nutritional outcomes

\begin{tabular}{|c|c|c|c|c|c|c|}
\hline \multirow[b]{2}{*}{ Outcome } & \multirow[b]{2}{*}{ No. of trials } & \multirow[b]{2}{*}{ Concordance } & \multicolumn{2}{|c|}{ Partial discordance } & \multicolumn{2}{|c|}{ Complete discordance } \\
\hline & & & Nutrition better ${ }^{\star}$ & Clinical better† & Nutrition better ${ }^{\star}$ & Clinical better \\
\hline \multicolumn{7}{|l|}{ Energy intake } \\
\hline Mortality & 31 & 42 & 29 & & 29 & \\
\hline Infections & 22 & 32 & 23 & & 45 & \\
\hline Total comp & 20 & 30 & 20 & & 50 & \\
\hline Dur'n hosp & 18 & 44 & 17 & & 39 & \\
\hline \multicolumn{7}{|l|}{ Protein intake } \\
\hline Mortality & 18 & 22 & 33 & & 39 & 6 \\
\hline Infections & 13 & 23 & 23 & & & 54 \\
\hline Total comp & 9 & 11 & 33 & & 56 & \\
\hline Dur'n hosp & 8 & 50 & 25 & & 25 & \\
\hline \multicolumn{7}{|l|}{ Weight gain } \\
\hline Mortality & 56 & 40 & 23 & 2 & 29 & 5 \\
\hline Infections & 36 & 31 & 8 & & 56 & 6 \\
\hline Total comp & 34 & 41 & 12 & 3 & 38 & 6 \\
\hline Dur'n hosp & 14 & 50 & 7 & 14 & 21 & 7 \\
\hline \multicolumn{7}{|l|}{$\mathrm{N}$ balance } \\
\hline Mortality & 36 & 36 & 42 & & 22 & \\
\hline Infections & 30 & 43 & 17 & & 40 & \\
\hline Total comp & 31 & 48 & 16 & & 35 & \\
\hline Dur'n hosp & 25 & 56 & 8 & & 36 & \\
\hline \multicolumn{7}{|l|}{ Albumin } \\
\hline Mortality & 56 & 29 & 18 & 20 & 25 & 9 \\
\hline Infections & 37 & 38 & 16 & 8 & 32 & 5 \\
\hline Total comp & 35 & 43 & 11 & 9 & 29 & 9 \\
\hline Dur'n hosp & 24 & 50 & 8 & 4 & 21 & 17 \\
\hline \multicolumn{7}{|l|}{ TSF thickness } \\
\hline Mortality & 30 & 27 & 10 & 20 & 33 & 10 \\
\hline Infections & 24 & 13 & 25 & 4 & 42 & 17 \\
\hline Total comp & 18 & 22 & 17 & 6 & 28 & 28 \\
\hline Dur’n hosp & 8 & 63 & & 13 & 13 & 13 \\
\hline \multicolumn{7}{|l|}{ MAC } \\
\hline Mortality & 16 & 50 & 17 & 13 & 13 & 7 \\
\hline Infections & 12 & 33 & 17 & 8 & 25 & 17 \\
\hline Total comp & 12 & 42 & 17 & 17 & 8 & 17 \\
\hline Dur'n hosp & 4 & 50 & & & 25 & 25 \\
\hline \multicolumn{7}{|l|}{ MAMC } \\
\hline Mortality & 21 & 24 & 19 & 5 & 48 & 5 \\
\hline Infections & 19 & 11 & 11 & 16 & 63 & \\
\hline Total comp & 10 & 30 & 10 & 10 & 50 & \\
\hline Dur'n hosp & 5 & 40 & 20 & & 40 & \\
\hline \multicolumn{7}{|l|}{ Transferrin } \\
\hline Mortality & 26 & 35 & 19 & 19 & 23 & 4 \\
\hline Infections & 17 & 41 & 12 & & 41 & 6 \\
\hline Total comp & 17 & 29 & 6 & 24 & 35 & 6 \\
\hline Dur'n hosp & 12 & 25 & 8 & & 42 & 25 \\
\hline \multicolumn{7}{|l|}{ Prealbumin } \\
\hline Mortality & 18 & 33 & 39 & 6 & 22 & \\
\hline Infections & 16 & 38 & 6 & & 56 & \\
\hline Total comp & 15 & 60 & 13 & & 27 & \\
\hline Dur'n hosp & 9 & 44 & & & 56 & \\
\hline Skin tests & & & & & & \\
\hline Mortality & 12 & 42 & 17 & 17 & 25 & \\
\hline Infections & 8 & 25 & 38 & 13 & 25 & \\
\hline Total comp & 5 & 60 & 20 & 20 & & \\
\hline Dur'n hosp & 5 & 40 & 20 & 20 & 20 & \\
\hline TLC & & & & & & \\
\hline Mortality & 6 & 33 & 17 & 33 & 17 & \\
\hline Infections & 3 & 67 & & & 33 & \\
\hline Total comp & 7 & 57 & 14 & & 29 & \\
\hline Dur'n hosp & 4 & 75 & & & & 25 \\
\hline
\end{tabular}

Comp, complications; dur'n hosp, duration of hospitalization; TSF, triceps skinfold; MAC, mid-arm circumference; MAMC, mid-arm muscle circumference; TLC, total lymphocyte count.

*The effect of the therapy was more beneficial on the nutritional outcome than on the clinical outcome, e.g. if the clinical outcome was 'no different', the nutritional one was 'better' or the nutritional outcome was 'no difference' while the clinical outcome was worse.

†The effect of the therapy was more beneficial on the clinical outcome than on the nutritional outcome, e.g. if the nutritional outcome was 'no different', the clinical one was 'better' or the clinical outcome was 'no difference' while the nutritional outcome was worse. 


\section{References}

Baker JP, Detsky AS, Wesson DE, Wolman SL, Stewart S, Whitewall J, Langer B \& Jeejeebhoy KN (1982) Nutritional assessment. A comparison of clinical judgment and objective measurements. New England Journal of Medicine 306, 969-972.

Buzby GP, Mullen JL, Matthews DC, Hobbs CL \& Dosato EF (1980) Prognostic nutritional index in gastrointestinal surgery. American Journal of Surgery 139, 160-167.

Cochrane Injuries Group Albumin Reviewers (1998) Human albumin administration in critically ill patients: systematic review of randomised controlled trials. British Medical Journal 317, 235-240.

Dudrick SJ \& Ruberg RL (1971) Principles and practice of parenteral nutrition. Gastroenterology 61, 901-910.

Dudrick SJ, Wilmore DW, Vars HM \& Rhoads JE (1968) Longterm parenteral nutrition with growth, development, and positive nitrogen balance. Surgery 64, 134-142.

Fletcher JP \& Little JM (1986) A comparison of parenteral nutrition and early postoperative enteral feeding on the nitrogen balance after major surgery. Surgery 100, 21-24.

HIV Surrogate Marker Collaborative Group (2000) Human immunodeficiency virus Type 1RNA level and CD4 count as prognostic markers and surrogate end points: a meta-analysis. AIDS Research and Human Retrovirus 16, 1123-1133.

Keys A (1962) Caloric deficiency and starvation. In Clinical Nutrition, 2nd ed., pp. 122-136 [N Jolliffe, editor]. New York: Harper and Brothers.

Koretz RL (1995) Intravenous albumin and nutrition support: going for the quick fix. Journal of Parenteral and Enteral Nutrition 19, 166-171.

Koretz RL, Lipman TO \& Klein S (2001) AGA technical review - Parenteral nutrition. Gastroenterology 121, 970-1001.

Reinhardt GF, Myscofski JW, Wilkens DB, Dobrin PB, Mangan JE Jr \& Stannard RT (1980) Incidence and mortality of hypoalbuminemic patients in hospitalized veterans. Journal of Parenteral and Enteral Nutrition 4, 357-359.

Rhoads JE, Vars HM \& Dudrick SJ (1981) The development of intravenous hyperalimentation. Surgical Clinics of North America 61, 429-435.

Studley HO (1936) Percentage of weight loss. A basic indicator of surgical risk in patients with chronic peptic ulcer. Journal of the American Medical Association 106, 458-460.

Wilkes MM \& Navickis PJ (2001) Patient survival after human albumin administration. Annals of Internal Medicine 135, 149-164.

\section{Appendix}

Randomized trials that have reported both clinical and nutritional outcomes

\section{Enteral nutrition:}

Bastow MD, Rawlings J \& Allison SP (1983) Benefits of supplementary tube feeding after fractured neck of femur: a randomised controlled trial. British Medical Journal 287, $1589-1592$.

Beier-Holgersen R \& Boesby S (1996) Influence of postoperative enteral nutrition on postsurgical infections. Gut 39, 833-835.

Cabre E, Gonzalez-Huix F, Abad-Lacruz A, Esteve M, Acero D, Fernandez-Banares F, Xiol X \& Gassull MA (1990) Effect of total enteral nutrition on the short-term outcome of severely malnourished cirrhotics. Gastroenterology 98, 715-720.
Calvey H, Davis M \& Williams R (1985) Controlled trial of nutritional supplementation, with and without branched chain amino acid enrichment, in treatment of acute alcoholic hepatitis. Journal of Hepatology 1, 141-151.

Carr CS, Ling KDE, Boulos P \& Singer M (1996) Randomised trial of safety and efficacy of immediate postoperative enteral feeding in patients undergoing gastrointestinal resection. British Medical Journal 312, 869-871.

Daniels L, Davidson GP, Martin AJ \& Pouras T (1989) Supplemental nasogastric feeding in cystic fibrosis patients during treatment for acute exacerbation of chest disease. Australian Paediatric Journal 25, 164-167.

De Ledinghen V, Beau P, Mannant P-R, Borderie C, Ripault MP, Silvain C \& Beauchant M (1997) Early feeding or enteral nutrition in patients with cirrhosis after bleeding from esophageal varices? A randomized controlled study. Digestive Diseases and Sciences 42, 536-541.

Fletcher JP \& Little JM (1986) A comparison of parenteral nutrition and early postoperative enteral feeding on the nitrogen balance after major surgery. Surgery 100, 21-24.

Hartgrink HH, Wille J, Konig P, Hermans J \& Breslau PJ (1998) Pressure sores and tube feeding in patients with a fracture of the hip: a randomized clinical trial. Clinical Nutrition 17, 287-292.

Hasse JM, Blue LS, Liepa GU, Goldstein RM, Jennings LW, Mor E, Husberg BS, Levy MF, Gonwa TA \& Klintmalm GB (1995) Early enteral nutrition support in patients undergoing liver transplantation. Journal of Parenteral and Enteral Nutrition 19, 437-443.

Heslin MJ, Latkany L, Leung D, Brooks AD, Hochwald SN, Pisters PWT, Shike M \& Brennan MF (1997) A prospective, randomized trial of early enteral feeding after resection of upper gastrointestinal malignancy. Annals of Surgery 226 , 567-580.

Kearns PJ, Young H, Garcia G, Blaschke T, O'Hanlon G, Rinki M, Sucher K \& Gregory P (1992) Accelerated improvement of alcoholic liver disease with enteral nutrition. Gastroenterology 102, 200-205.

Moore EE \& Jones TN (1986) Benefits of immediate jejunostomy feeding after major abdominal trauma - a prospective, randomized study. Journal of Trauma 26, 874-881.

Sagar S, Harland P \& Shields R (1979) Early postoperative feeding with elemental diet. British Medical Journal i 293-295.

Shukla HS, Rao RR, Banu N, Gupta RM \& Yadav RC (1984) Enteral hyperalimentation in malnourished surgical patients. Indian Journal of Medical Research 80, 339-346.

Singh G, Ram RP \& Khanna SK (1998) Early postoperative enteral feeding in patients with nontraumatic intestinal perforation and peritonitis. Journal of the American College of Surgery 187, 142-146.

Smith RC, Hartemink RJ, Hollinshead JW \& Gillett DJ (1985) Fine bore jejunostomy feeding following major abdominal surgery: a controlled randomized clinical trial. British Journal of Surgery 72, 458-461.

Spirtos NM \& Ballon SC (1988) Needle catheter jejunostomy: a controlled, prospective, randomized trial in patients with gynecologic malignancy. American Journal of Obstetrics and Gynecology 158, 1285-1290.

Sullivan DH, Nelson CL, Bopp MM, Puskarich-May CL \& Walls RC (1998) Nightly enteral nutrition support of elderly hip fracture patients: a phase I trial. Journal of the American College of Nutrition 17, 155-161.

Tandon SP, Gupta SC, Sinha SN \& Naithani YP (1984) Nutritional support as an adjunct therapy of advanced cancer patients. Indian Journal of Medical Research 80 , 180-188. 
Watters JM, Kirkpatrick SM, Morris SB, Shamji FM \& Wells GA (1997) Immediate postoperative enteral feeding results in impaired respiratory mechanics and decreased mobility. Annals of Surgery 226, 369-380.

Parenteral nutrition:

Abel RM, Fischer JE, Buckley MJ, Barnett GO \& Austen G (1976) Malnutrition in cardiac surgical patients. Archives of Surgery 111, 45-50.

Bonau RA, Ang SD, Jeevanandam M \& Daly JM (1984) Highbranched chain amino acid solutions: relationship of composition to efficacy. Journal of Parenteral and Enteral Nutrition 8, 622-627.

Brans YW, Sumners JE, Dweck HS \& Cassady G (1974) Feeding the low birth weight infant: orally or parenterally? Preliminary results of a comparative study. Pediatrics 54, 15-22.

Carpentier YA, Fetelian D, Barroy JP, Jaspar N \& Bracamonte M (1985) Effect of TPN on substrate metabolism in the postoperative course. Clinical Nutrition 4, Suppl., Abstr O.23.

Charuhas PM, Fosberg KL, Bruemmer B, Aker SN, Leisenring W, Seidel K \& Sullivan KM (1997) A double-blind randomized trial comparing outpatient parenteral nutrition with intravenous hydration: effect of resumption of oral intake after marrow transplantation. Journal of Parenteral and Enteral Nutrition 21, 157-161.

Clamon GH, Feld R, Evans WK, Weiner RS, Moran EM, Blum RH, Kramer BS, Makuch RW, Hoffman FA \& DeWys WD (1985) Effect of adjuvant central iv hyperalimentation on the survival and response to treatment of patients with small cell lung cancer: a randomized trial. Cancer Treatment Reports 69, 167-177.

DeCicco M, Panarello G, Fantin D, Veronesi A, Pinto A, Zagonel V, Monfardini S \& Testa V (1993) Parenteral nutrition in cancer patients receiving chemotherapy: effects of toxicity and nutritional status. Journal of Parenteral and Enteral Nutrition 17, 513-518.

Dickinson RJ, Ashton MG, Axon ATR, Smith RC, Yeung CK \& Hill GL (1980) Controlled trial of intravenous hyperalimentation and total bowel rest as an adjunct to the routine therapy of acute colitis. Gastroenterology 79, 1199-1204.

Donaldson SS, Wesley MN, Ghavimi F, Shils ME, Suskind RM \& DeWys WD (1982) A prospective randomized clinical trial of total parenteral nutrition in children with cancer. Medical and Pediatric Oncology 10, 129-139.

Drott C, Unsgaard B, Schersten T \& Lundholm K (1988) Total parenteral nutrition as an adjuvant to patients undergoing chemotherapy for testicular carcinoma: protection of body composition - a randomized, prospective study. Surgery 103, 499-506.

Fan S-T, Lo C-M, Lai ECS, Chu K-M, Liu C-L \& Wong J (1994) Perioperative nutritional support in patients undergoing hepatectomy for hepatocellular carcinoma. New England Journal of Medicine 33, 1547-1552.

Fletcher JP \& Little JM (1986) A comparison of parenteral nutrition and early postoperative enteral feeding on the nitrogen balance after major surgery. Surgery 100, 21-24.

Ghavimi F, Shils ME, Scott BF, Brown M \& Tamaroff M (1982) Comparison of morbidity in children requiring abdominal radiation and chemotherapy, with and without total parenteral nutrition. Journal of Pediatrics 101, 530-537.

Gunn T, Reaman G, Outerbridge EW \& Colle E (1978) Peripheral total parenteral nutrition for premature infants with the respiratory distress syndrome: a controlled study. Journal of Pediatrics 92, 608-613.

Gys T, Peeters R \& Hubens A (1990) The value of short-term peripheral parenteral nutrition after colorectal surgery: a comparative study with conventional postoperative intravenous fluid. Acta Chirurgica Belgica 90, 234-239.

Hansell DT, Davies JWL, Shenkin A, Garden OJ, Burns HJG \& Carter DC (1989) The effects of an anabolic steroid and peripherally administered intravenous nutrition in the early postoperative period. Journal of Parenteral and Enteral Nutrition 13, 349-358.

Hays DM, Merritt RJ, White L, Ashley J \& Siegel SE (1983) Effect of total parenteral nutrition on marrow recovery during induction therapy for acute nonlymphocytic leukemia in childhood. Medical and Pediatric Oncology 11, 134-140.

Heim ME (1986) Adjuvante parenterale ernahrung bei zytostatischer chemotherapie (Adjuvant parenteral nutrition with cytostatic chemotherapy). Infusionstherapie 13, 115-121.

Holter AR \& Fischer JE (1977) The effects of perioperative hyperalimentation on complications in patients with carcinoma and weight loss. Journal of Surgical Research 23, 31-34.

Hwang T-L, Mou S-C \& Chen M-F (1993) The importance of a source of sufficient protein in postoperative hypocaloric partial parenteral nutrition support. Journal of Parenteral and Enteral Nutrition 17, 254-256.

Hyde D \& Floch MH (1984) The effect of peripheral nutritional support and nitrogen balance in acute pancreatitis. Gastroenterology 86, 1119.

Hyltander A, Drott C, Unsgaard B, Tolli J, Korner U, Arfvidsson B \& Lundholm K (1991) The effect on body composition and exercise performance of home parenteral nutrition when given as adjunct to chemotherapy of testicular carcinoma. European Journal of Clinical Investigation 21, 413-420.

Issell BF, Valdivieso M, Zaren HA, Dudrick SJ, Freireich EJ, Copeland EW \& Bodey GP (1978) Protection against chemotherapy toxicity by iv hyperalimentation. Cancer Treatment Reports 62, 1139-1143.

Jensen S (1985) Clinical effects of enteral and parenteral nutrition preceding cancer surgery. Medical Oncology and Tumor Pharmacotherapy 2, 225-229.

Jin D, Phillips M \& Byles JE (1999) Effects of parenteral nutrition support and chemotherapy on the phasic composition of tumor cells in gastrointestinal cancer. Journal of Parenteral and Enteral Nutrition 23, 237-241.

Kinsella TJ, Malcolm AW, Bothe A, Valerio D \& Blackburn GL (1981) Prospective study of nutritional support during pelvic irradiation. International Journal of Radiation Oncology and Biological Physics 7, 543-548.

Kirvela O, Stern RC, Askanazi J, Doershuk CF, Rothkopf MM \& Katz DP (1993) Long-term parenteral nutrition in cystic fibrosis. Nutrition 9, 119-126.

Lorenzoni K (1981) Postoperative infusionstherapie in der abdominalchirurgie (Postoperative infusion therapy in abdominal surgery). Wiener Medizinische Wochenschrift $\mathbf{1 3 1}$ 485-491.

Lough M, Watkins R, Campbell M, Carr K, Burnett A \& Shenkin A (1990) Parenteral nutrition in bone marrow transplantation. Clinical Nutrition 9, 97-101.

McIntyre PB, Powell-Tuck J, Wood SR, Lennard-Jones JE, Lerebours E, Heckelsweher P, Gaimiche J-P \& Colin R (1986) Controlled trial of bowel rest in the treatment of severe acute colitis. Gut 27, 481-485

Marin VB, Rebollo MGJ, Castillo-Duran CD, Lopez MTS, Sanabria MS, Moraga FM, Castro F \& Barrera FO (1999) Controlled study of early postoperative parenteral nutrition in children. Journal of Pediatric Surgery 34, 1330-1335.

Mattioli S, Lassari A, Lerro F, DiSimone MP, Pilotti V, Raspadori A, D’Ovidio F \& Gozzetti G (1993) Nutrizione parenterale totale dopo interventi di chirurgia digestiva 
maggiore (Total parenteral nutrition after undergoing major digestive surgery). Chirurgia 6, 129-133.

Melchior J-C, Chastang C, Gelas P, Carbonnel F, Zazzo J-F, Boulier A, Cosnes J, Bouletreau P \& Messing B (1996) Efficacy of 2-month total parenteral nutrition in AIDS patients: a controlled randomized prospective trial. AIDS $\mathbf{1 0}$, 379-384.

Muller JM, Keller HW, Brenner U, Walter M \& Holzmuller W (1986) Indications and effects of preoperative parenteral nutrition. World Journal of Surgery 10, 53-63.

Naveau S, Pelletier G, Poynard T, Attali P, Poitrine A, Buffet C, Etienne J-P \& Chaput J-C (1986) A randomized clinical trial of supplementary parenteral nutrition in jaundiced alcoholic cirrhotic patients. Hepatology 6, 270-274.

Neuvonen P \& Salo M (1984) Effects of preoperative parenteral nutrition on cell-mediated immunity in malnourished patients. Clinical Nutrition 3, 197-201.

Nixon DW, Moffitt S, Lawson DH, Ansley J, Lynn MJ, Kutner MH, Heymsfield SB, Wesley M, Chawla R \& Rudman D (1981) Total parenteral nutrition as an adjunct to chemotherapy of metastatic colorectal cancer. Cancer Treatment Reports $\mathbf{6 5}$, Suppl. 5, 121-128.

O'Mahony JB, McIrvine AJ, Palder SB, See-Young L, Saporoschetz IB, Wilmore DW \& Mannick JA (1984) The effect of short term postoperative intravenous feeding upon cellmediated immunity and serum suppressive activity in well nourished patients. Surgery, Gynecology, and Obstetrics 159, 27-32.

Pildes RS, Ramamurthy RS, Cordero GV \& Wong PWK (1973) Intravenous supplementation of 1-amino acids and dextrose in low-birth-weight infants. Journal of Pediatrics 82, 945-950.

Popp MB, Fisher RI, Wesley R, Aamodt R \& Brennan MF (1981) A prospective randomized study of adjuvant parenteral nutrition in the treatment of advanced diffuse lymphoma: influence on survival. Surgery 90, 195-203.

Reilly J, Mehta R, Teperman L, Cemaj S, Tzakis A, Yanaga K, Ritter P, Rezak A \& Makowka L (1990) Nutritional support after liver transplantation: a randomized prospective study. Journal of Parenteral and Enteral Nutrition 14, 386-391.

Roberts S, Miller JE \& Pineiro LA (2000) Is total parenteral nutrition beneficial in breast cancer patients after autologous marrow or blood transplantation? Journal of Parenteral and Enteral Nutrition 24, S11-S12.

Samuels ML, Selig DE, Ogden S, Grant C \& Brown B (1981) Iv hyperalimentation and chemotherapy for stage III testicular cancer: a randomized study. Cancer Treatment Reports $\mathbf{6 5}$, $615-627$.

Sax HC, Warner BW, Talamini MA, Hamilton FN, Bell RH, Fischer JE \& Bower RH (1987) Early total parenteral nutrition in acute pancreatitis: lack of beneficial effects. American Journal of Surgery 153, 117-124.

Serrou B, Cupissol D, Plagne R, Boutin P, Chollet P, Carcassone Y \& Michel FB (1982) Follow-up of a randomized trial for oat cell carcinoma evaluating the efficacy of peripheral intravenous nutrition (PIVN) as adjunct treatment. Recent Results in Cancer Research 80, 246-253.

Shamberger RC, Brennan MF, Goodgame JT, Lowry SF, Maher MM, Wesley RA \& Pizzo PA (1984) A prospective, randomized study of adjuvant parenteral nutrition in the treatment of sarcomas: results of metabolic and survival studies. Surgery 96, 1-12.

Shike M, Russell DM, Detsky AS, Harrison JE, McNeill KG, Shepherd FA, Feld R, Evans WK \& Jeejeebhoy KN (1984) Changes in body composition in patients with small-cell lung cancer. Annals of Internal Medicine 101, 303-309.
Simms JM, Oliver E \& Smith JAR (1980) A study of total parenteral nutrition (TPN) in major gastric and esophageal resection for neoplasia. Journal of Parenteral and Enteral Nutrition 4, 422.

Simon D \& Galambos JT (1988) A randomized controlled study of peripheral parenteral nutrition in moderate and severe alcoholic hepatitis. Journal of Hepatology 7, 200-207.

Smith JAR, Simms JM, Williams JL \& Woods HF (1984) Is total parenteral nutrition necessary after total cystectomy? - A pilot study. Clinical Nutrition 3, 55-58.

Solassol C, Joyeaux H \& Dubois JB (1979) Total parenteral nutrition (TPN) with complete nutritive mixtures: an artificial gut in cancer patients. Nutrition and Cancer 1, 13-18.

Song Y, Kang XM \& Xia XR (1993) Clinical observation on short term nutritional support in the treatment of advanced chronic obstructive pulmonary disease. Chung Hua Nei Ko Tsa Chih 32, 819-822.

Thompson BR, Julian TB \& Stremple JF (1981) Perioperative total parenteral nutrition in patients with gastrointestinal cancer. Journal of Surgical Research 30, 497-500.

Vaidya UV, Bhave SA \& Pandit AN (1995) Parenteral nutrition (PN) in the management of very low birthweight (VLBW) babies - a randomized controlled trial. Indian Pediatrics 32, 165-170.

Valdivieso M, Frankmann C, Murphy WK, Benjamin RS, Barkley HT, McMurtrey MJ, Jeffries DG, Welch SR \& Bodey GP (1987) Long-term effects of intravenous hyperalimentation administered during intensive chemotherapy for small cell bronchogenic carcinoma. Cancer 59, 362-369.

Van Eys J, Copeland EM, Cangir A, Taylor G, Teitell-Cohen B, Carter P \& Ortiz C (1980) A clinical trial of hyperalimentation in children with metastatic malignancies. Medical and Pediatric Oncology 8, 63-73.

Weisdorf SA, Lysne J, Wind D, Haake RJ, Sharp HL, Goldman A, Schissel K, McGlave PB, Ramsay NK \& Kersey JH (1987) Positive effect of prophylactic total parenteral nutrition on long-term outcome of bone marrow transplantation. Transplantation 43, 833-838.

Wu C-W, Meng HC, Mok K-T, Kung S-P, Lin S-H, Liu W-Y \& Peng F-K (1995) Effect of total parenteral nutrition on the postoperative outcome in aged patients with gastric cancer. Digestive Surgery 12, 164-170.

Yamada N, Koyama H, Hioki K, Yamada T \& Yamamoto M (1983) Effect of postoperative total parenteral nutrition (TPN) as an adjunct to gastrectomy for advanced gastric carcinoma. British Journal of Surgery 70, 267-274.

Protein-sparing therapy:

Achord JL (1987) A prospective randomized clinical trial of peripheral amino acid-glucose supplementation in acute alcoholic hepatitis. American Journal of Gastroenterology 82, 871-875.

Bonkovsky HL, Fiellin DA, Smith GS, Slaker DP, Simon D \& Galambos JT (1991) A randomized, controlled trial of treatment of alcoholic hepatitis with parenteral nutrition and oxandrolone. I. Short-term effects on liver function. American Journal of Gastroenterology 86, 1200-1208.

Bryan MH, Wei P, Hamilton JR, Chance GW \& Swyer PR (1973) Supplemental intravenous alimentation in low-birth-weight infants. Journal of Pediatrics 82, 940-944.

Culebras-Fernandez JM, de la Hoz Riesco M, Villares Garcia C, Hurtado Fernandez-Llamazares G \& Alonos Villalba A (1987) Improvement of the nutritional condition with hypocaloric peripheral parenteral nutrition (HPPN) in the immediate postoperative period of elective abdominal surgery. Infusionstherapie 14, 202-208. 
Figueras J, Puig P, Rafecas A, Bianchi A, Hernandez F, Pi F \& Colomer J (1988) Postoperative hypocaloric parenteral nutrition. Acta Chirurgica Scandinavica 154, 435-438.

Figueras J, Ramos E. Llop JM, San-Juan N \& Marti J (1990) Effect of balanced amino acid solution on protein metabolism after surgery. A clinical study. Infusionstherapie 17, 100-103.

Figueras-Felip J, Rafecas-Renau A, Sitges-Serra A, Puig-Gris P, Pi-Siques F, Colomer J \& Bianchi-Cardona (1986) Does peripheral hypocaloric parenteral nutrition benefit the postoperative patient? Results of a multicentric randomized trial. Clinical Nutrition 5, 117-121.

Freund H, Hoover HC, Atamian S \& Fischer JE (1979) Infusion of the branched chain amino acids in postoperative patients. Annals of Surgery 190, 18-23.

Garden OJ, Smith A, Harris NWS, Shenkin A, Sim AJW \& Carter DC (1983) The effect of isotonic amino acid infusions on serum proteins and muscle breakdown following surgery. British Journal of Surgery 70, 79-82.

Hansell DT, Davies JWL, Shenkin A, Garden OJ, Burns HJG \& Carter DC (1989) The effects of an anabolic steroid and peripherally administered intravenous nutrition in the early postoperative period. Journal of Parenteral and Enteral Nutrition 13, 349-358.

Hensle TW (1978) Protein-sparing therapy in cystectomy patients. Journal of Urology 119, 355-358.

Hogbin BM, Smith AM \& Craven AH (1984) An evaluation of peripheral essential amino acid infusion following major surgery. Journal of Parenteral and Enteral Nutrition 8, $511-514$.
Hwang T-L, Mou S-C \& Chen M-F (1993) The importance of a source of sufficient protein in postoperative hypocaloric partial parenteral nutrition support. Journal of Parenteral and Enteral Nutrition 17, 254-256.

Hyde D \& Floch MH (1984) The effect of peripheral nutritional support and nitrogen balance in acute pancreatitis. Gastroenterology 86, 1119.

Jimenez Jimenez FJ, Ortiz Leyba C, Jimenez Jimenez LM, Garcia Valdecasas MS \& Garnacho Montero J (1995) Study of hypocaloric peripheral parenteral nutrition in postoperative patients (Europan project) Clinical Nutrition 14, $88-96$.

Lopez-Hellin J, Lopez-Lara M, Mercader S, Gemar E, GarciaArumi E, Sabin P, Baena JA \& Schwartz S (1997) Early curbing of protein hypercatabolism in postoperative patients by nutritional support with glucose plus amino acids, but not with glucose alone. Clinical Nutrition 16, 67-73.

Mezey E, Caballeria J, Mitchell MC, Pares A, Herlong HF \& Rodes J (1991) Effect of parenteral amino acid supplementation on short-term and long-term outcomes in severe alcoholic hepatitis: a randomized controlled trial. Hepatology $\mathbf{1 4}$ 1090-1096.

Nasrallah SM \& Galambos JT (1980) Aminoacid therapy of alcoholic hepatitis. Lancet i, 1276-1277.

Sitges-Serra A, Figueras-Felip J, Alastrue-Vidal A, Jaurrieta-Mas E \& Rafecas-Renau A (1986) A randomized trial on the effect of isotonic amino acid infusion on postoperative complications and short life plasma protein concentrations. Infusionstherapie 13, 210-214. 